\title{
A Bibliography of Thomas Bird Mosher
}

\section{A. Bibliographies}

Hatch, Benton L. A Check List of the Publications of Thomas Bird Mosher of Portland Maine. MDCCCxI: MDCcCCxxiII. Boston: Printed at the Gehenna Press for University of Massachusetts Press, I966. With a biographical essay by Ray Nash (pp. 9-32). Review Times Literary Supplement 26 Oct. 1967: 1024.

Ransom, Will. 'The Mosher Press.' In Selective Check Lists of Press Books. New York: Philip Duschnes, 1945-50. Reprint I963. Ransom also surveys Mosher's printing in his Private Presses and Their Books (New York, 1929).

B. Selected Works on Thomas Bird Mosher and the Mosher Press

Biographical sources (general): Who's Who. 4th ed. 1906-07; Encyclopaedia of American Biography (pp. 247-48); Dictionary of American Biography 7 (1962): 278-79. See also Ray Nash in Hatch, above; and Norman Strouse, below.

Blanck, Jacob. 'News from the Rare Booksellers.' Publisher's Weekly I4I (I9 Jan. I942): 2 IO-I I. On transfer of business to Williams Book Store, Boston.

Chapman, Alfred C. 'Thomas Bird Mosher.' Colby Library Quarterly, Ser. IV, No. I3 (Feb. I958): 229-44.

Dunn, Charles. [Thomas Bird Mosher]. Publisher's Weekly I 5 Sept. 1923.

Fuller, Marion Cobb. 'Thomas Bird Mosher.' Maine Library Bulletin I 2 (Jan. I927): 62-65. Quotes extensively from Dunn, above.

Gomme, Laurence. 'The Pirate of Portland - Thomas Bird Mosher.' Maine Digest 2 (Winter 1968): 90-93.

Huntress, Keith Gibson. 'Thomas Bird Mosher, a Biographical and Literary Study.' Unpublished Ph.D. dissertation, University of Illinois, I942.

Le Gallienne, Richard. 'Thomas Bird Mosher: An Appreciation.' Forum 5 I (Jan. I9I4): I24-29. Reprinted as Introduction to The Mosher Books (I9I4) and in the Index to the Bibelot (1915); separately printed by 
Mosher (I9I 5). Le Gallienne also published an article on Mosher entitled 'In Praise of a Literary Pirate' in the Literary Digest International Book Review 2 (Oct. I924): 777-78.

MacKay, Kay. "“A Pirate Half Pardoned ...": Thomas Bird Mosher.' Antiquarian Book Monthly Review I4 (Jan. I987): I6-2 I.

[Matthews, Annie Harmon]. Thomas Bird Mosher of Portland Maine. Portland: The Southwork-Anthoensen Press, I94I. With a Preface and an essay on Mosher by Edward F. Stevens (pp. 21-26). Published for Fred V. Matthews.

Miller, Spencer. 'Dedication.' In Amphora: A Second Collection. Portland: Mosher, 1926. Cited in the text and elsewhere in the Bibliography as Amphora 2.

Morley, Christopher. 'A Golden String.' In Amphora 2: I09-I 3. Reprinted from Saturday Review of Literature i I July i925, and later as 'A Dogwood Tree,' in John Mistletoe. New York: Doubleday, I93 I.

Nash, Ray. 'The Poet and the Pirate.' New Colophon, II, pt. 8 (Feb. I950): 3 I I-2 I. See also Nash's biographical account in Hatch's Check List. Needham, Wilbur. 'An Attempt at Appreciation of a Rare Spirit.' In The Mosher Books (1923). Reprinted from Chicago Evening Post 20 April I923: 4 .

Newton, A. Edward. 'The Book Itself.' In This Book-Collecting Game. Boston: Little, Brown, I928; section on Mosher: pp. I I9-25.

Patterson, Eleanor C. 'Salve et Vale.' In The Bibelot: General Index. Portland: Mosher, I9I 5: v-xiv.

Philpott, Anthony J. 'Mosher of Portland, Me.' Globe (Boston) 20 Dec. I897. A lengthy interview with Mosher occupying two full columns.

Pottle, Frederick A. 'Aldi Discipulus Americanus.' In Amphora 2: i I7-26. Reprinted from Literary Review 29 (Dec. I923).

'A Publisher Who Saw His Dream Come True.' Current Opinion 76 (Feb. I924): I77-79. Quotes extensively from Dunn, above.

Reedy, William Marion. 'The Ending of The Bibelot.' In The Bibelot: General Index (I91 5): I87-91.

[Sale Catalogue of the Books of Thomas Bird Mosher]. A two-part sale conducted over four days. New York: Parke-Bernet Galleries, Io- I I May, I I-I2 Oct., I948.

Steinhardt, Maxwell. 'An Appreciation of Mosher.' Quarto Club Papers I (I926-27): 45-54.

Stevens, Edward F. 'The Kelmscott Influence in Maine.' Colby Library Quarterly 6 (March I944): 92-95.

Strouse, Norman H. The Passionate Pirate. North Hills, PA: Bird and Bull Press, 1964. A preliminary version was presented to the Rowfant Club of Cleveland, 25 Nov. I960. 
An Exhibition of Books from the Press of Thomas Bird Mosher, from the Collection of Norman H. Strouse. Privately Printed, [I967].

Thompson, Susan Otis. 'Thomas Bird Mosher: The Aesthetic Pirate.' In American Book Design and William Morris. New York: Bowker, I977: I90-97.

Van Trump, James D. and Arthur P. Ziegler, Jr. 'Thomas Bird Mosher Publisher and Pirate.' Book Collector I I (I962): 293-3 I2. Borrows heavily from Huntress.

Smith, Simon Nowell. 'Note I89: Mosher and Bridges.' Book Collector I I (I962): 482-83.

White, William. 'Thomas Bird Mosher and A Shropshire Lad.' Serif 5 (I968): 30-33.

\section{Contemporary Controversies over Mosher's Piracies}

The Critic (1895-97): after the opening salvo by L.W. Hatch (23 Nov. 95: 355) and a letter from Lang (I 8 Jan. 96: 48), a long precis and letter by Mosher, with an editorial comment titled 'Mr. Lang and the Ethics of Reprinting' followed (I I July 96: 75 I-52); then came a summary of Lang's letter in Illustrated London News with a reply by Mosher 22 Aug. 96: I23); 'The Publishing Privateer' (ro Oct. 96: 2 I9); another letter from Lang on an announced further reprint (7 Nov. 96: 280); 'Mr. Mosher Strikes Back,' a letter (28 Nov. 96: 349); and a final letter from Lang (2 Jan. 97: I2).

Publishers' Circular: 23 Jan. I909: I I 3-I4. Four responses - from Andrew Lang, George Meredith, Maurice Hewlett, and Vernon Lee - to a survey conducted by the editor, R.B. Marston, on 'Mosherizing,' his euphemism for 'book-stealing,' with an editorial attack on Mosher's audacious compounding of his piracies by distributing his books in England.

The Times (I9 I4): James H. Blackwood, President of the Publishers' Association in Great Britain (7 March: 9); Grant Richards (Io March: 7); R.B. Marston (ro March: 7); James H. Blackwood (I I March: 9). 
Appendix I

Thomas Bird Mosher: Biographical Summary

I852-I870 Formative Years. TBM b. I I September I 852 in Biddeford, Maine, the son of Benjamin (a ship owner and sea-captain) and Mary Merrill Mosher (two sisters: Sara Elizabeth and Lila Josephine Primrose). The two trips твм made to sea with his father in I862 - the first a daring run down the Atlantic coast to New Orleans, transporting Northern troops, the other with the entire family to England - were a prelude to the grand tour 'before the mast' made in his adolescence that would so dramatically shape his later life. In I 866, after completing grammar school in Boston, instead of continuing with his formal education, he joined his father in Hamburg and embarked on a three-year voyage of literary discovery opened up for him by the 34 volumes of Bell's British Theatre (I792) that his father bought for him in Germany.

I870-I882 Apprenticeship and Marriage. Returning to Portland in the summer of г 870, твм enrolled briefly (perhaps for a single day) in Phillips Exeter Academy; afterwards, he took a job as clerk with Dresser and McLellan in Portland, a firm dealing in law reports, stationer's supplies, and textbooks. On ro December I 870, he secretly married Eleanor S. Dresser; the couple remarried on 4 July I 87 I, and took up residence in Portland. Ellie deserted him on I $3_{3}$ September I 879 and moved to New York City; твм divorced her three years later, on 25 September I882. In 1875 , while on a brief summer vacation in Springfield, Massachusetts, TBM met Leopold Lobsitz (I 858-I 879), with whom he shared many literary interests and to whom in I9I 2 he dedicated his Amphora. During these years, твм worked at various jobs in Portland, New York, Philadelphia, and, for a longer period, in St. Louis, where he clerked in a bookstore.

I 882-I 890 Businessman. In December I882, TBM became a junior partner, with his former employer, Ruel T. McLellan, in the firm of McLellan, Mosher \& Co. which gave him both business and publishing experience; in these years, he published a preface to George J. Varney's A Brief History of Maine, his first piece of extended writing, and began collecting books in earnest. His father died on 12 December I 885 . In I890, his business failed, and твм, nearly 40, cast his eyes towards publishing. 
I890- Publisher and Litterateur: твм launched his publishing career in premises at 37 (later 45) Exchange St., Portland, Maine, and issued his first work, a reprint of Meredith's Modern Love, in October I891. On 2 July I 892, he married Anna M. Littlefield, who bore him two sons (Harrison Hume, b. 8 January I 896, and Thomas Bird, Jr., b. 3 I March I907, the year of TBM's mother's death). In I 894, he issued his first catalogue, and in 1895 started The Bibelot (which ran till I9I4); the same year he was elected to the Grolier Club. In I90I, he travelled to England, where he met many of his authors. Bowdoin College awarded him an honorary M.A. in I906. He suffered a stroke in 1909, and died on 3 I August I923. During the 30 years he ran the Mosher Press, he published nearly 800 separate items.

I923- Postlude. Following твм's death, Flora Lamb, his secretary since I897, carried on the business with Mrs. Mosher, issuing reprints and a few privately printed books. The firm was sold to the Williams Book Store of Boston in December I94 I. TBM's library was sold at ParkeBernet Galleries on IO-I I May I948. The bulk of TBM's papers are at Harvard.

Appendix 2

The Mosher Series, The Bibelot, and Annual Catalogues

\section{A. Books in Series: Based on Hatch's Check List and} Mosher's Catalogues

I. ENGLISH REPRINT SERIES (I89I-I 894; 3 vols., printed on one side of leaf; never reprinted):

I: George Meredith Modern Love (HI)

III: Robert Bridges The Growth of Love $(\mathrm{H} 5)$

States: Io Large paper Japan vellum \$ I 2.50 (post 4to)

50 Large paper $\$ 7.50$

400 Small paper \$2.00-\$2.50 (post 8vo)

Approximate print-run: I,350 copies 
2. BIBELOT SERIES (I893-I897; Io vols.; modelled on Aldine format, printed in Italic type; narrow $8 \mathrm{vo}, 4^{1 / 4} \times 8^{1 / 4^{\prime \prime}}$; never reprinted):

I: [твм] Songs of Adieu (H3)

x: Mary F. Robinson An Italian Garden (H37)

States: 725 (I-VI), 925 (VII-x) Van Gelder paper \$ I.00

25 (I-IV), 50 (V-VI), IOO (VII-X) Japan vellum \$2.50

Approximate print-run: 8,225 copies

3. OLD WORLD SERIES (I895-I909; 50 vols.; foolscap 8vo, 4 x 7"; the most popular and frequently reprinted of the Mosher series. Edition statements are not always accurate; some editions are Japan vellum only; edition size varies, as in the case of the I I th [actually I 2 th] edition of Burton's Kasîdah, printed in I 500 copies - the largest ows printing and the most often reprinted):

I: Edward Fitzgerald, trans. The Rubáiyát (HI I)

L: A.C. Swinburne Félise (H464)

States: 925 Van Gelder paper \$1.00 50- Ioo Japan vellum $\$ 2.50$ /Copies bound in old-style boards \$ I.25; some copies were also bound in flexible, olive-green leather.)

Approximate print-run: I29, I 20 copies

4. BROCADE SERIES (I 895-I905; 50 vols.; small I6mo, 31/4 X 51/4"; frequently reprinted):

I: Walter Pater The Child in the House (HI4)

L: Marcel Schwob The Children's Crusade (H327)

State: 425 copies on Japan vellum, issued in brocade-patterned boxes (hence the name) at 75 cents, or boxed in sets.

Approximate print-run: 71,825 copies 
5. MISCELLANEOUS SERIES (I 895-I923; 96 vols.; frequently reprinted):

I: George Russell ('A.E.') Homeward Songs by the Way (H I3)

[XCVI]: Marcel Schwob The Children's Crusade (H7OI)

States: Edition size, state, format, and price vary, ranging from Wilde's Poetical Works (XLIII, I908, H435), a quarto of over 400 pages, published in 750 copies on hand-made paper at $\$ 4.00$, and 25 copies on Japan vellum at $\$ 8.00$, which went through only a single edition, to John Hay's In Praise of Omar (IV, I898, H67), a small quarto of a dozen pages, printed in 925 copies on Van Gelder paper, priced at 25 cents and Ioo copies on Japan vellum at $\$$ I.oo, which went through 8 editions and was the second most often reprinted volume in the series. The 4 copies on pure vellum, noted by Hatch, following Mosher's practice, are unpriced in his catalogue and were probably already sold before the edition was issued.

Approximate print-run: 86,720 copies

6. REPRINTS FROM The Bibelot (I897-I902; I 2 vols.; small 4to; never reprinted):

I: Robert Louis Stevenson Father Damien (H47)

xII: J.W. Mackail William Morris: An Address (H223)

State: Issued in 25 (I-VI, VIII), 35 (IX-XI), and 50 (VII, XII) copies on Japan vellum $\$ 4.00$.

Approximate print-run: 320 copies

7. REPRINTS OF PRIVATELY PRINTED BOOKS (I 897-I902; I 2 vols.; two volumes only, Nos. I and VI, reprinted):

I: Walter Pater Essays from the 'Guardian' (H49) xIr: Photolithographic reprint of the 1859 Rubáiyát (H226)

States: Format, edition size (from 250-774, including paper, Japan vellum, and pure vellum), state, and price vary.

Approximate print-run: 8,329 
8. VEST POCKET SERIES (I 899-I9I 3; 25 vols.; small I6mo, 23/4 X 51/4"; Io volumes reprinted):

I: Rubáiyát (H I 2 I)

xxv: Charles Johnston From the Upanishads (H59I)

States: Issued in blue wrappers at 30 cents, limp cloth at 50 cents, flexible leather at 75 cents, Japan vellum at $\$$ I.oo.

Approximate print-run: number of copies printed unknown

9. QUARTO SERIES (I 899-I904; IO vols.; never reprinted):

I: A.C. Swinburne Laus Veneris (H 122 )

$\mathrm{x}$ : A.C. Swinburne Tristram of Lyonesse and Other Poems (H295)

States: 450 copies on Van Gelder paper \$5.00-\$ I0.00

25 (I-VI, X), 35 (VII-IX) on Japan vellum \$ I 5.00-\$20.00

4 on Pure Roman vellum

(Two distinct typographic formats for prose and poetry.

Following his custom, твм restricted sales of early volumes, once stocks were low, to subscribers to the entire series.)

Approximate print-run: 770 copies

IO. LYRIC GARLAND (I9O3-I9I3; 26 vols.; small 8vo, 4⿳⺈⿴囗十 X $7^{\prime \prime}$; half the titles were reprinted, Yeats's The Land of Heart's Desire going through I 2 editions):

I: W.B. Yeats The Land of Heart's Desire ( $\mathrm{H2} 60)$

xxvi: Ernest Dowson The Pierrot of the Minute (H592)

States: 950 on Van Gelder paper at 50 cents

I OO (I-XIX), 50 (XX-XXVI) on Japan vellum at \$ I.OO

in first edition only

Io (I-VIII), 7 (IX-X), 5 (XI-XII) pure Roman vellum

(Complete sets were sold on subscription.)

Approximate print-run: 57,454 
I I. IDEAL SERIES OF LITTLE MASTERPIECES (I906-I909; I2 vols.; small 8vo; bound in green decorated wrappers; only two volumes, Nos. I and v, reprinted):

I: Edgar Prestage, trans. The Sweet Miracle by Eça de Queiroz (H36o) xIr: Katharine Tynan A Little Book for John O'Mahony's Friends (H476)

States: Issued on Van Gelder paper 50 cents and Japan vellum \$ I.00; boxed sets priced at $\$ 6.00$ and $\$$ I 2.00 .

Approximate print-run: number of copies printed unknown

I2. GOLDEN TEXT SERIES (I9O8-I9I I; 8 vols.; small 4to, bound in coloured paper wrappers; only two volumes, Nos. I and III, reprinted):

I: Francis Thompson The Hound of Heaven (H442)

vIII: Ralph Waldo Emerson Threnody and Other Poems (H54I)

States: 925 Van Gelder paper, coloured wrappers 50 cents 200 Van Gelder paper, marbled boards 60 cents roo copies Japan vellum \$ I.OO

Approximate print-run: 1,225

I 3. VENETIAN SERIES (I9IO-I9I3; 7 vols.; small 4to, bound in I 8th-C decorated Italian paper wrappers; never reprinted):

I: A.C. Swinburne Siena (H5 I 5 )

vII: Mary F. Robinson Songs from an Italian Garden (H593)

States: Issued on Van Gelder paper at 50 cents and Japan vellum at $\$ \mathrm{I} .00$; boxed sets of the first three volumes were available at $\$ 1.50$ and $\$ 3.00$.

Approximate print-run: number of copies printed unknown

I4. PRIVATELY PRINTED EDITIONS (I9I2-I9I5; IO vols.):

I: Elizabeth Alden Curtis The Norsemen: A Drama in Four Acts (H7 I6)

$\mathrm{x}$ : Thomas S. Jones The Voice in the Silence (H736)

States: Size of edition, format, and price of volumes vary.

Approximate print-run: 2,575 
I 5. LYRA AMERICANA /I9I 5-I920; 6 vols.; only three of the six volumes were reprinted):

I: Thomas S. Jones The Rose Jar (H625)

vi: Lizette Woodworth Reese A Branch of May: Poems (H680)

States: 450 on Van Gelder paper, bound in Fabriano boards with slip case at $\$$ I.OO

25 copies (first edition only) on Japan vellum

with slip case at $\$ 2.00$

Approximate print-run: 4,650

\section{B. The Bibelot}

The Bibelot was issued in 240 monthly parts and collected annually in 20 volumes from January I 895 to December I9I4. Two indexes were published by Mosher, the first, of Vols. I-I 2 (I 906), the second, a General Index compiled by Milton James Ferguson (I9I5). In I926, W.H. Wise and Co. published a 'Testimonial Edition' of The Bibelot with a completely new index. At its inception, monthly parts of The Bibelot, issued in blue wrappers, were priced at 5 cents, an annual subscription at 50 cents; by I 903 the journal was available only by subscription at 75 cents. Published in a small quarto format, The Bibelot was printed on Van Gelder paper, with a few copies on Japan vellum; annual cases for binding were available from the publisher for 50 cents; or Mosher would bind them in old-style boards for $\$$ I.00. Complete sets, in a limited edition of 500, were advertised in the last issue, in old-style blue paper boards at $\$ 50$ or in dark blue Holliston Library buckram at $\$ 55$. A hundred sets were reserved for custom binding in half Roxburghe, calf, or levant, 'price available on request.' According to Keith Huntress, The Bibelot never exceeded 2000 subscribers.

\section{Annual Catalogues}

In I 894, Mosher issued the first of 30 annual catalogues, variously entitled A List of Books in Belles Lettres and A List of Books Issued in Limited Editions, until I902, when the title The Mosher Books was adopted. All catalogues were issued both in wrappers and boards. Mosher's contributions to these catalogues were reprinted in the two collections of Amphora, the first published in I9I2 (H560); Amphora: A Second Collection appeared in I926, three years after Mosher's death. 


\section{Summary}

Mosher employed three Portland printers: the English Reprint Series was printed by Brown, Thurston Company; most of the Brocade Series was printed by George D. Loring; all the rest were printed by Smith \& Sale. Although Mosher is known for his adaptations of the Aldine anchor and dolphin device, it was in fact used on only seven series, asterisked in the list below. A complete set of Mosher books in first editions includes:

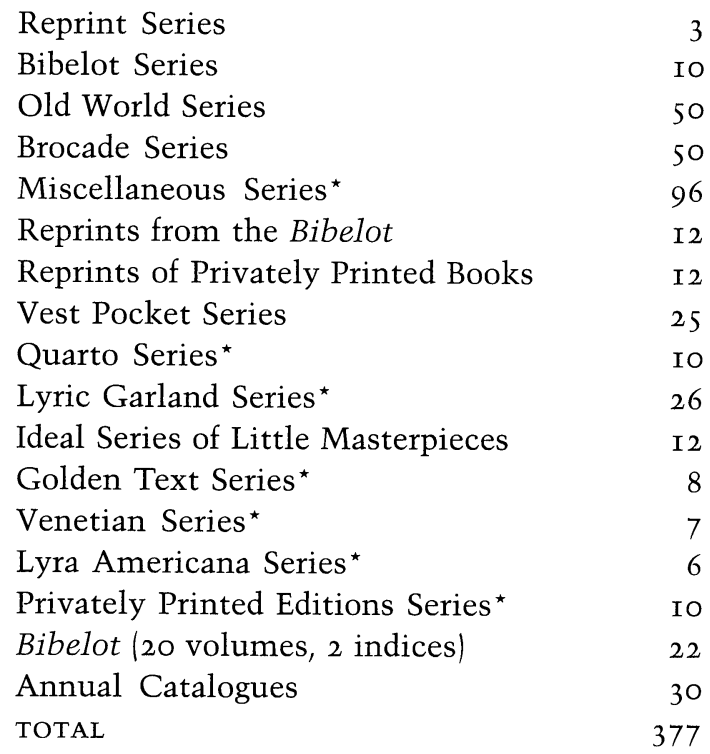

This total does not include reprints (even those containing new material), different states of the same edition, or private printings not in the series.

\section{E. Publication Statistics}

Based on available statistics relating to the number of titles in the respective series, the size of printings, and the number of reprinted editions cited in Hatch, the total number of copies produced by Mosher comes to 372,538. If figures for The Bibelot, the annual catalogues, and the three series for which no press-runs are known (the Vest Pocket, Venetian, and Ideal Series of Little Masterpieces) are added in, Mosher total production certainly exceeded 400,000. Some sense of Mosher's publishing income, as opposed to the book-selling side of his business, can be derived by multiplying known print-runs by prices, but lacking Mosher's business accounts of printer's costs, postage, discounts, and other expenses, no such estimate has been attempted. 
Appendix 3

A Frequency Survey of Mosher Authors

In selecting material for his several series and for the Bibelot, Mosher, guided solely by his own taste, repeatedly reprinted his favourite authors. This table records the seven most popular writers in the Mosher canon, as determined by their joint appearance in series and in the Bibelot. Writers published in four or more series are listed in the first column, with number of titles in parentheses and Bibelot frequency in brackets; Bibelot authors are listed in the second column, with the number of separate parts devoted to works by and on, the latter in parentheses, followed by series frequency in brackets.

Series
I. Swinburne: 8 (I 5 ) [4]
2. Wilde: 6 (I7) [1 2]
3. Pater: 6 (I6; I with Morris) [2]
4. Fiona Macleod: 6 (I6) [7]
5. Rossetti: 6 (9) [17]
6. Morris: 5 (I 8; I with Pater) [I]
7. Stevenson: 5 (I 5 ) [6]
8. Symonds: $4(5)[5]$
9. Browning: $4(5)[\mathrm{x}]$
Io. Hewlett: 4 (4) [19]
I I. Arnold: 4 (4) [r4]
I2. Fitzgerald: $4(4)[x]$

\section{Bibelot}
I. Morris: I4 (I); 2 doubles [6]
2. Pater: I I [3]
3. Symons: II I double [I6]
4. Swinburne: $8[\mathrm{I}]$
5. Symonds: 8 (I) [8]
6. Stevenson: 7 [7]
7. Fiona Macleod: [4]
8. V. Lee: 4 ; I double [I 4 ]
9. Lang: 4; I double [I 8]
Io. J.W. Mackail: 4 [x]
II. Henley: 4 [x]
I2. Wilde: 3 [2] 
Appendix 4

The Mosher Books: A Chronological Analysis

\begin{tabular}{|c|c|c|c|c|c|c|c|c|c|}
\hline \multicolumn{10}{|c|}{ (Numbers in parentheses refer to Hatch entries; PP = privately printed books) } \\
\hline Year & \multicolumn{2}{|c|}{ Orig.eds. } & \multicolumn{2}{|c|}{ Reprints } & \multicolumn{2}{|c|}{ The Bibelot } & \multirow[t]{2}{*}{ Cats. } & \multirow[t]{2}{*}{$P P$} & \multirow{2}{*}{$\begin{array}{l}\text { SERIES and Notes } \\
\text { ENGLISH REPRINT (1) }\end{array}$} \\
\hline 1891 & 1 & (1) & & & & & & & \\
\hline 1893 & 2 & $(3-4)$ & & & & & & & BIBELOT (3) \\
\hline 1894 & 3 & $(5-7)$ & & & & & (8) & & First List of Books \\
\hline 1895 & 6 & $(9-14)$ & 2 & $(17-18)$ & 1 & (15) & (16) & & $\begin{array}{l}\text { The Bibelot Vol. 1; OLD } \\
\text { WORLD (11); MISCELLANEOUS } \\
\text { (13); BROCADE (14) }\end{array}$ \\
\hline 1896 & 8 & $(19-26)$ & 7 & $(29-35)$ & 2 & (27) & $(28)$ & & \\
\hline 1897 & 14 & $(36-49)$ & 11 & $(52-62)$ & 3 & (50) & (51) & & $\begin{array}{l}\text { REPRINTS FROM Bibelot (47); } \\
\text { \& FROM PRIV. PTD. BKS. (49) }\end{array}$ \\
\hline 1898 & 16 & $(63-78)$ & 22 & $(81-102)$ & 4 & (79) & (80) & 1 & \\
\hline 1899 & 20 & $(103-22)$ & 11 & $(125-35)$ & 5 & (123) & (124) & 2 & VEST POCKET/QUARTO (121-22) \\
\hline 1900 & 23 & $(136-58)$ & 20 & $(161-80)$ & 6 & (159) & $(160)$ & 1 & \\
\hline 1901 & 17 & $(181-97)$ & 10 & $(200-09)$ & 7 & (198) & (199) & 1 & \\
\hline 1902 & 21 & $(210-30)$ & 11 & $(233-43)$ & 8 & (231) & $(232)$ & 1 & \\
\hline 1903 & 19 & $(244-62)$ & 17 & $(265-81)$ & 9 & (263) & (264) & 1 & $\begin{array}{l}\text { LYRICAL GARLAND (260); List } \\
\text { retitled The Mosher Books }\end{array}$ \\
\hline 1904 & 17 & $(282-98)$ & 14 & $(301-14)$ & 10 & (299) & $(300)$ & 1 & \\
\hline 1905 & 17 & $(315-31)$ & 12 & $(344-49)$ & 11 & (332) & (333) & & \\
\hline 1906 & 16 & $(350-65)$ & 19 & $(369-87)$ & $\begin{array}{r}12 \\
\text { Index }\end{array}$ & $\begin{array}{l}(366) \\
(367)\end{array}$ & $(368)$ & & $\begin{array}{l}\text { IDEAL SERIES OF LITTLE } \\
\text { MASTERPIECES (260) }\end{array}$ \\
\hline 1907 & 13 & $(388-400)$ & 27 & $(403-29)$ & 13 & (401) & (402) & 1 & \\
\hline 1908 & 14 & $(430-43)$ & 17 & $(446-62)$ & 14 & (444) & $(445)$ & 1 & GOLDEN TEXT (442) \\
\hline 1909 & 16 & $(463-78)$ & 23 & $(481-503)$ & 15 & (479) & $(480)$ & 1 & \\
\hline 1910 & 14 & $(504-17)$ & 10 & $(520-29)$ & 16 & $(518)$ & $(519)$ & & VENETIAN (515) \\
\hline 1911 & 14 & $(530-43)$ & 10 & $(546-55)$ & 17 & $(544)$ & $(545)$ & 1 & \\
\hline 1912 & 10 & $(556-65)$ & 17 & $(568-84)$ & 18 & $(566)$ & $(567)$ & 7 & PRIV. PTD. EDITIONS (716) \\
\hline 1913 & 9 & $(585-93)$ & 11 & $(596-606)$ & 19 & $(594)$ & $(595)$ & 7 & \\
\hline 1914 & 5 & $(607-11)$ & 7 & $(614-20)$ & 20 & $(612)$ & (613) & 6 & \\
\hline 1915 & 7 & $(621-27)$ & 5 & $(630-34)$ & Index & $(628)$ & $(629)$ & 4 & LYRA AMERICANA (625) \\
\hline 1916 & 5 & $(635-39)$ & 12 & $(641-52)$ & & & $(640)$ & 2 & \\
\hline 1917 & 5 & $(653-57)$ & 4 & $(659-62)$ & & & $(658)$ & 5 & \\
\hline 1918 & 3 & $(663-65)$ & & $\mathrm{X}$ & & & $(666)$ & & \\
\hline 1919 & 3 & $(667-69)$ & 6 & $(671-76)$ & & & $(670)$ & 4 & \\
\hline 1920 & 4 & $(677-80)$ & 6 & $(682-87)$ & & & $(681)$ & 4 & \\
\hline 1921 & 1 & $(688)$ & 1 & $(690)$ & & & $(689)$ & 1 & \\
\hline 1922 & 1 & $(691)$ & 7 & $(693-99)$ & & & $(692)$ & 4 & \\
\hline 1923 & 2 & $(700-701)$ & & $\mathrm{x}$ & & & $(702)$ & 2 & \\
\hline TOTA & & 327 & & 319 & & & 30 & 59 & \\
\hline \multicolumn{10}{|c|}{ Summary } \\
\hline \multicolumn{3}{|c|}{ Original editions } & 327 & & & & & & \\
\hline \multicolumn{3}{|c|}{ Reprints } & 328 & \multicolumn{6}{|c|}{ (includes 9 Unlocated Trade editions in Appendix) } \\
\hline \multicolumn{3}{|c|}{ Private Printings } & 59 & \multicolumn{6}{|c|}{ (Hatch $703-61 ; 10$ in PRIV. PTD. EDNS. SER.) } \\
\hline \multicolumn{3}{|c|}{ Total books published } & 714 & \multirow{2}{*}{\multicolumn{6}{|c|}{ (includes two indices; 240 seperate numbers) }} \\
\hline \multicolumn{3}{|c|}{ The Bibelot } & 22 & & & & & & \\
\hline \multicolumn{3}{|c|}{ Catalogues (1894-1923) } & 30 & \multicolumn{6}{|c|}{ (ephemera not accounted for) } \\
\hline \multicolumn{3}{|c|}{ Total } & 766 & \multicolumn{6}{|c|}{ (1006 counting Bibelot numbers as seperate items) } \\
\hline
\end{tabular}




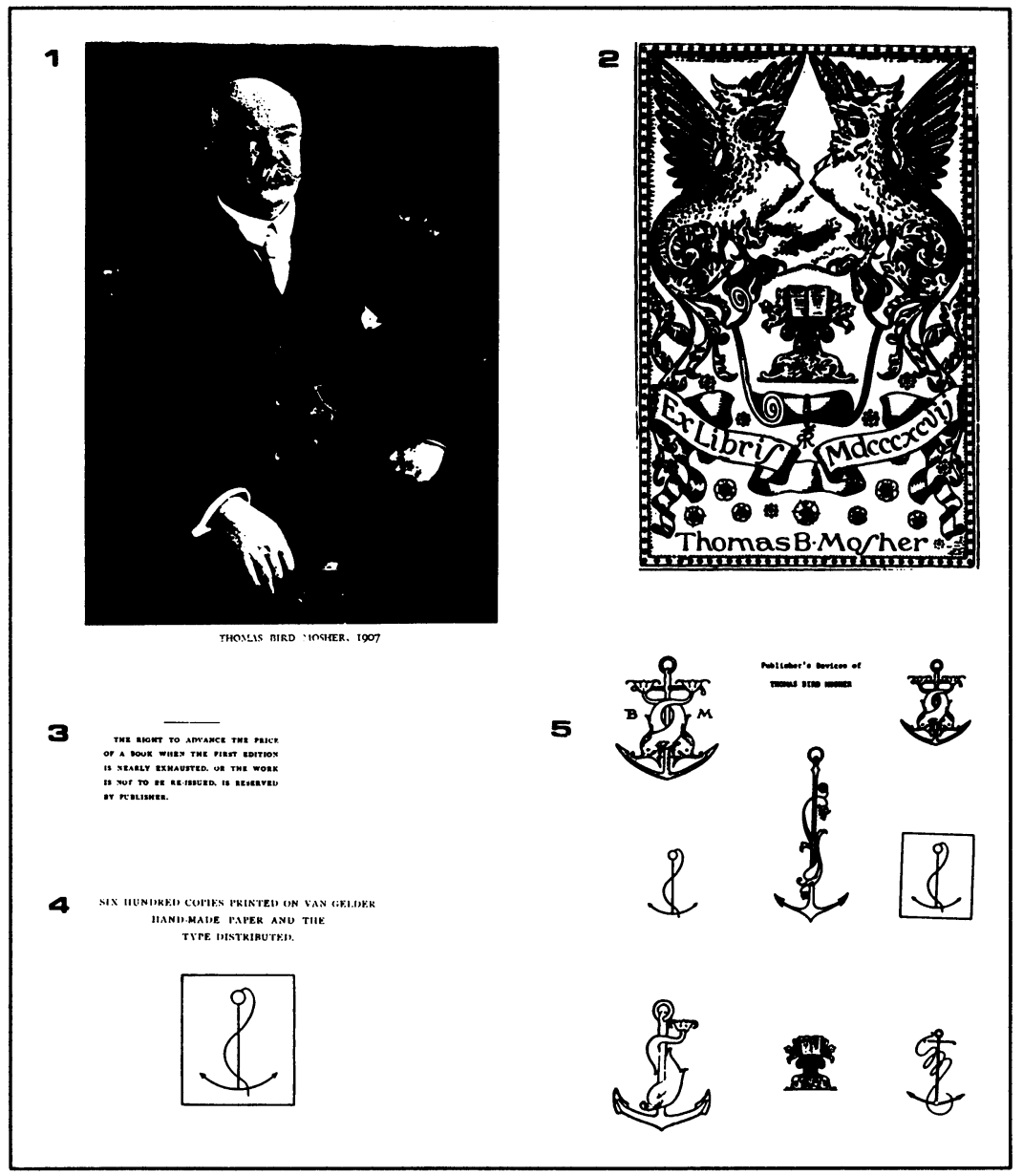

I. Thomas Bird Mosher at age fifty-five.

2. Mosher's book plate with provision for printed date of acquisition.

3. Policy statement on Mosher's practice of increasing prices on diminishing stocks.

4. A typical limitation certificate contained in all but three Mosher series.

5. Eight publisher's devices employed in the Mosher books, with a single exception variations on the anchor and dolphin motif of Aldus and Pickering, in one instance forming the initials твм. 


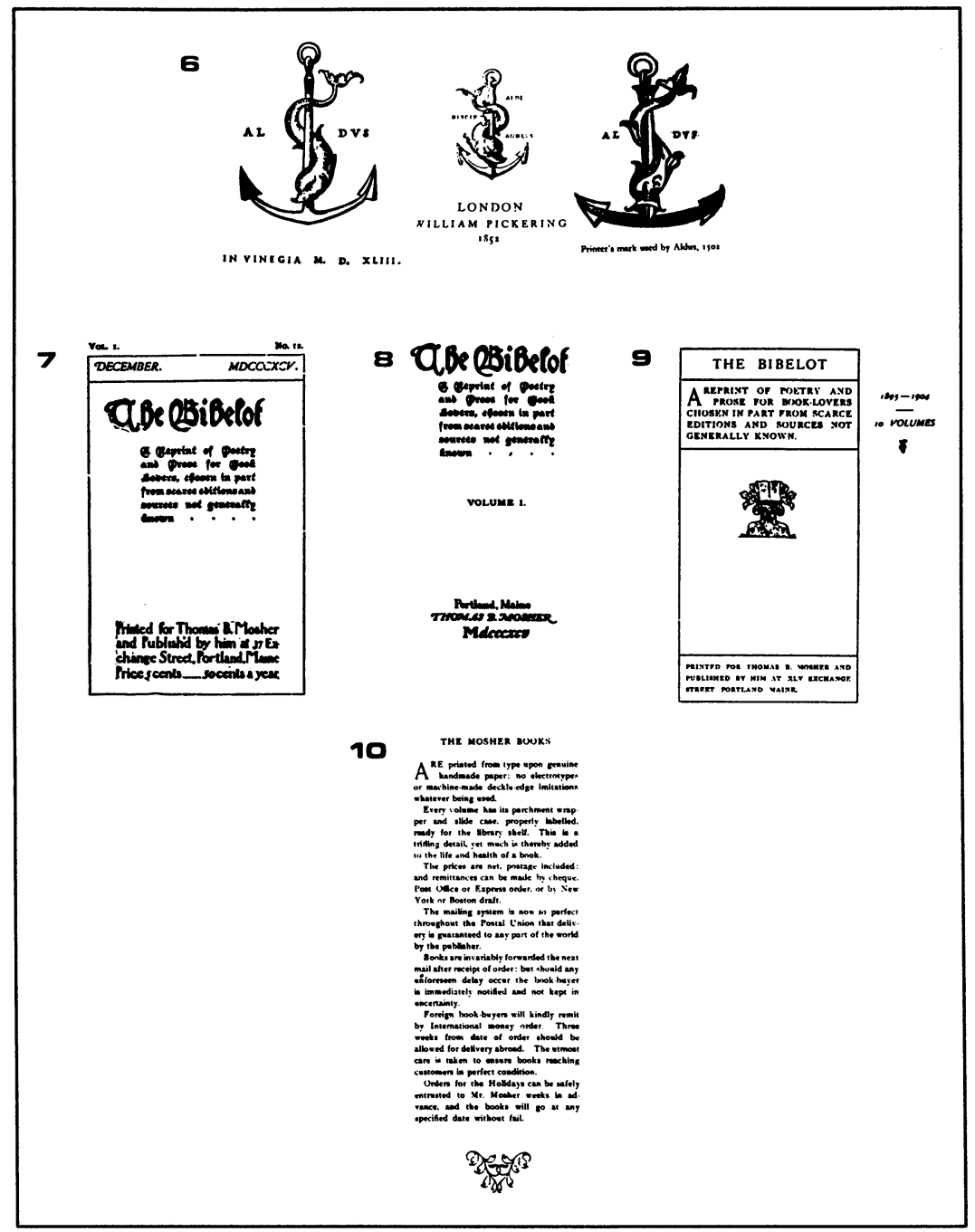

6. Dolphin and anchor devices of Aldus and Pickering.

7. Single number of Bibelot in blue wrappers for December I 895 .

8. Volume I of Bibelot (1895; H I 5 ).

9. Advertisement for the first ten volumes of the Bibelot (1905).

Io. Advertising flyer suitable for use as bookmark. 


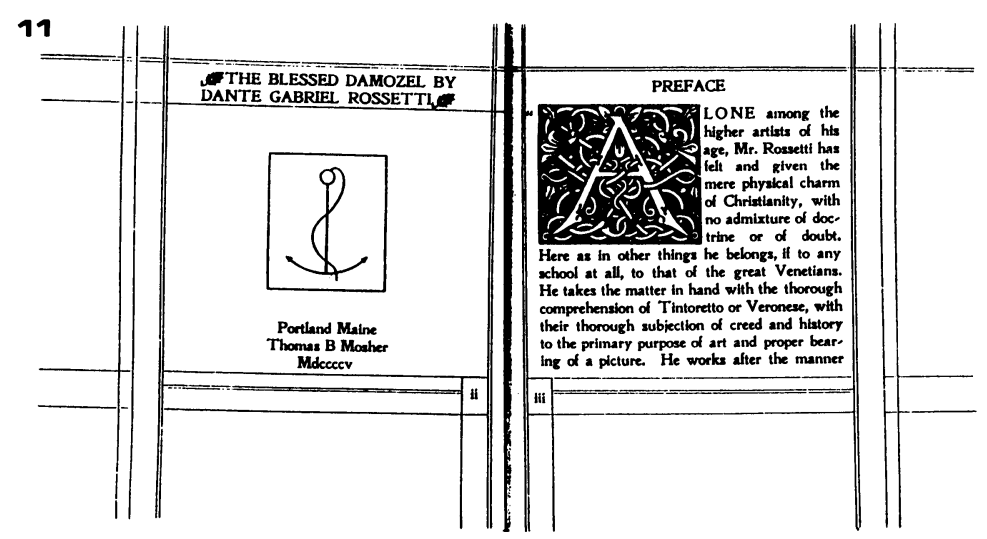

12

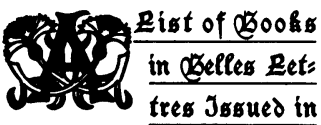

Cboice and Rimited Editions

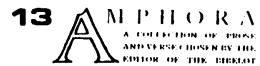

14 MODERN LUVE AND OTHER POEMS BY
GEOROE MEREDTY
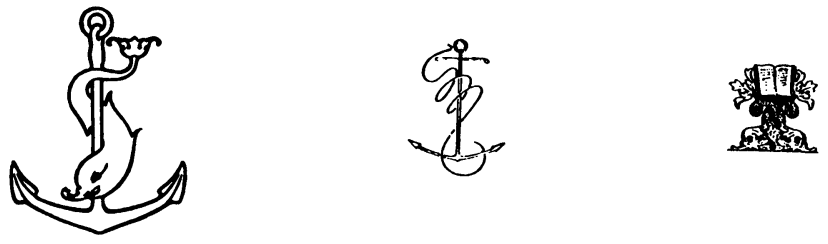

porttens preine

Ebomas os. Mosker

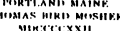

Purthed, Malose Mdcccreviy

I I. Dante Gabriel Rossetti's The Blessed Damozel, 3rd. ed. (Miscellaneous $\mathrm{XV}, \mathrm{I} 905 ; \mathrm{H} 34 \mathrm{O} ;$ Ist. ed. I9OI). The edition is modelled on the Vale Press edition of Rossetti's Hand and Soul (r 899).

I2. Mosher's catalogue for 1902 (H232), the last before the adoption of the permanent title The Mosher Books.

I3. Amphora, 4th. ed., I922 (H698; Ist. ed. I9I2).

I4. George Meredith's Modern Love and Other Poems (Old World XII, I898; H64). 

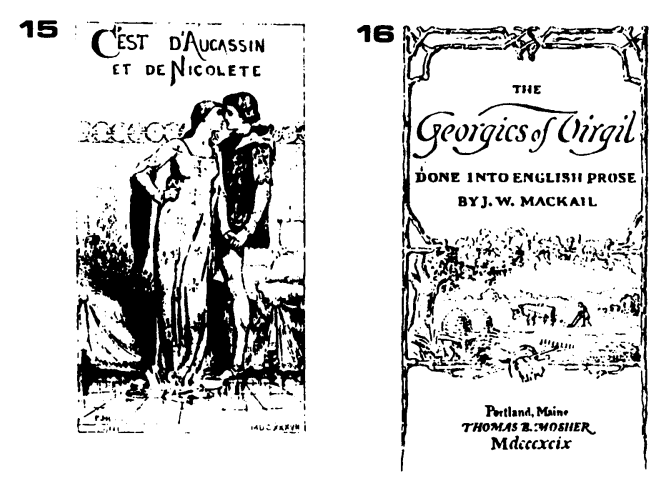

\section{Jึแ

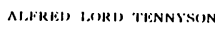

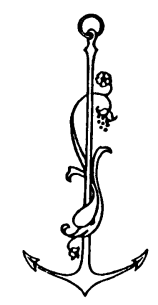

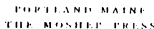

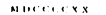

18

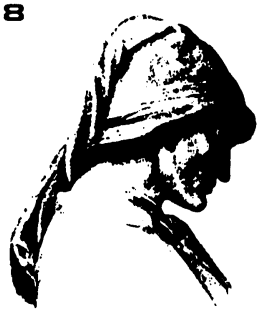

1) ANTEATVERONA "YMANTh

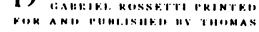

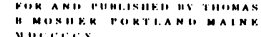

19 DREAMTHORP a cook or csshys wettestes in the COCNTRE T"
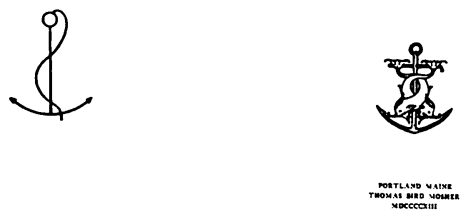

I 5. Illustrated frontispiece for Andrew Lang's Aucassin and Nicolete by P.H. Hood (Old World II, I 895; H I 2). This volume, a piracy of the limited London Nutt edition of $\mathrm{I} 886$, inaugurated the first controversy over Mosher's publishing practices.

I6. Paper cover of J.W. Mackail's translation of Virgil's Georgics, printed in green (Miscellaneous VI, I909; HI07).

17. Tennyson's In Memoriam, privately printed in 500 copies for Edward A. Woods (I92O; H754).

I 8. Frontispiece and title page of Rossetti's Dante at Verona (Venetian III, I9IO; H5 I7).

19. Title page of Alexander Smith's Dreamthorp (Miscellaneous LxIX, I9I3; H588). 


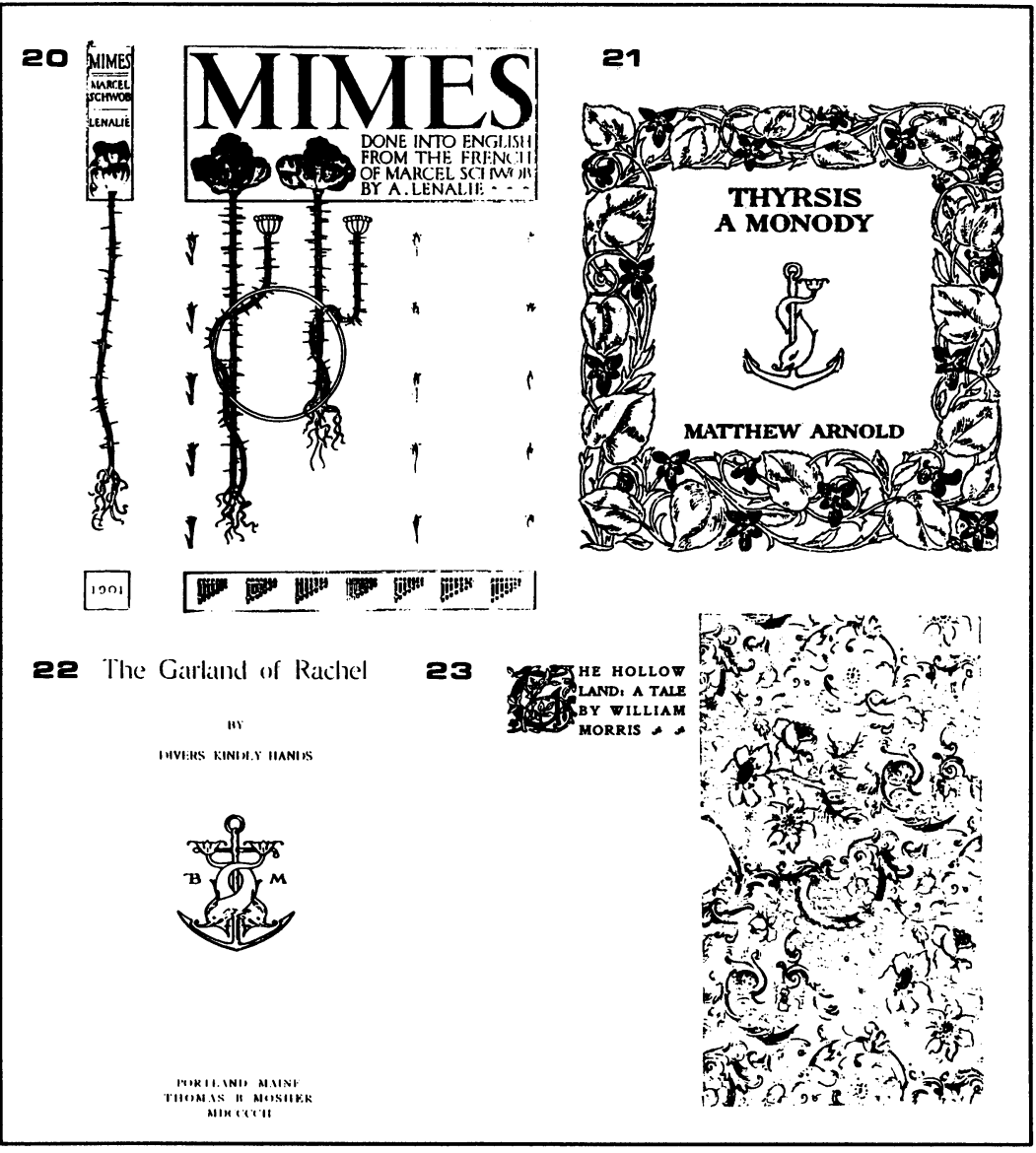

20. Spine and front cover art nouveau wrappers for Marcel Schwob's Mimes (Miscellaneous XVI, I9OI; HI 86).

2I. Decorated green stiff-wrapper cover for Matthew Arnold's Thyris: A Monody and The Scholar Gipsy (Golden Text XI, I9IO; H5 I4).

22. The Garland of Rachel by Diverse Kindly Hands (Reprints of Privately Printed Books XI, I9O2; H225). This reprint of the Daniel Press edition, one of the most handsome books produced by the Mosher Press, contains a list of Daniel Press Publications by Henry W. Poor.

23. Boxed copy of William Morris's The Hollow Land (Brocade xxII, I900; HI 48). The series was named after the box designs. 


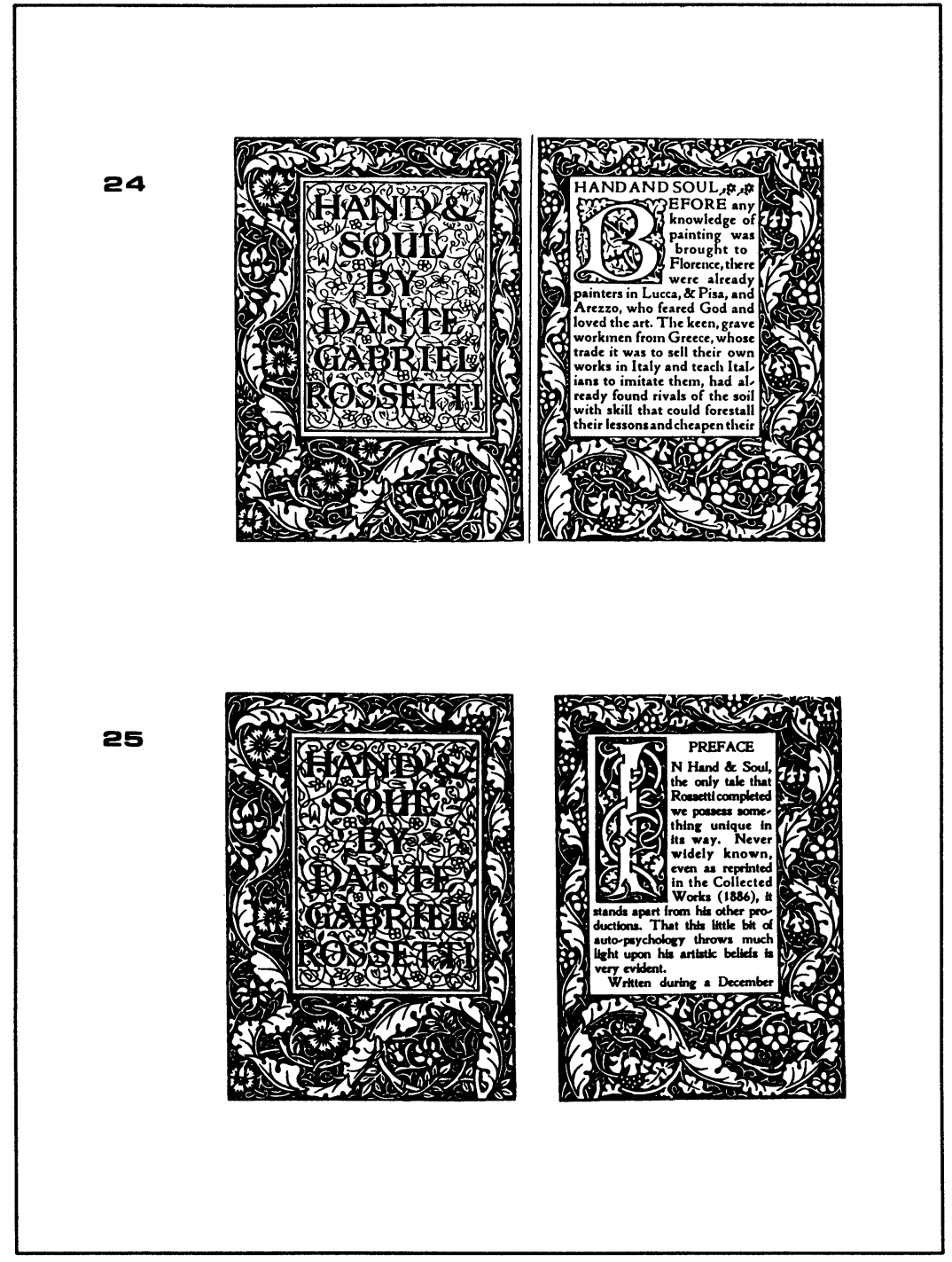

24. Kelmscott Press edition of Rossetti's Hand and Soul (I 895).

25. Mosher's quasi-facsimile of the Kelmscott edition (Miscellaneous viII, I 899; H IO9). 

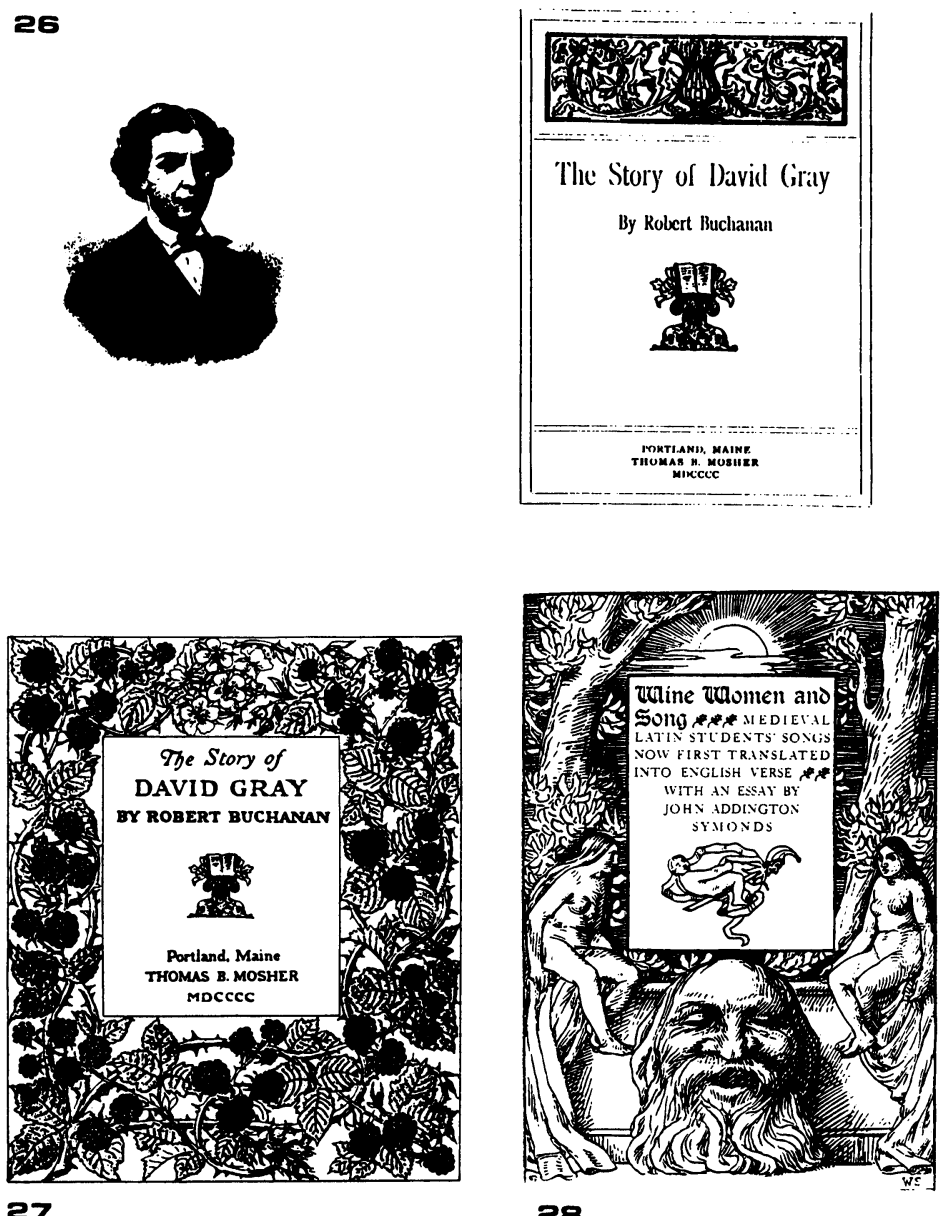

27

28

26. Frontispiece portrait and title page for David Gray.

27. Decorated cover wrappers in three colours of Robert Buchanan's The Story of David Gray (Miscellaneous XIV, I900; HI 44). The rooth Mosher title.

28. Illustrated title page of John Addington Symonds' Wine, Women and Song: Medieval Latin Students' Songs (Miscellaneous LxxxIV, I9I 8; H663). 


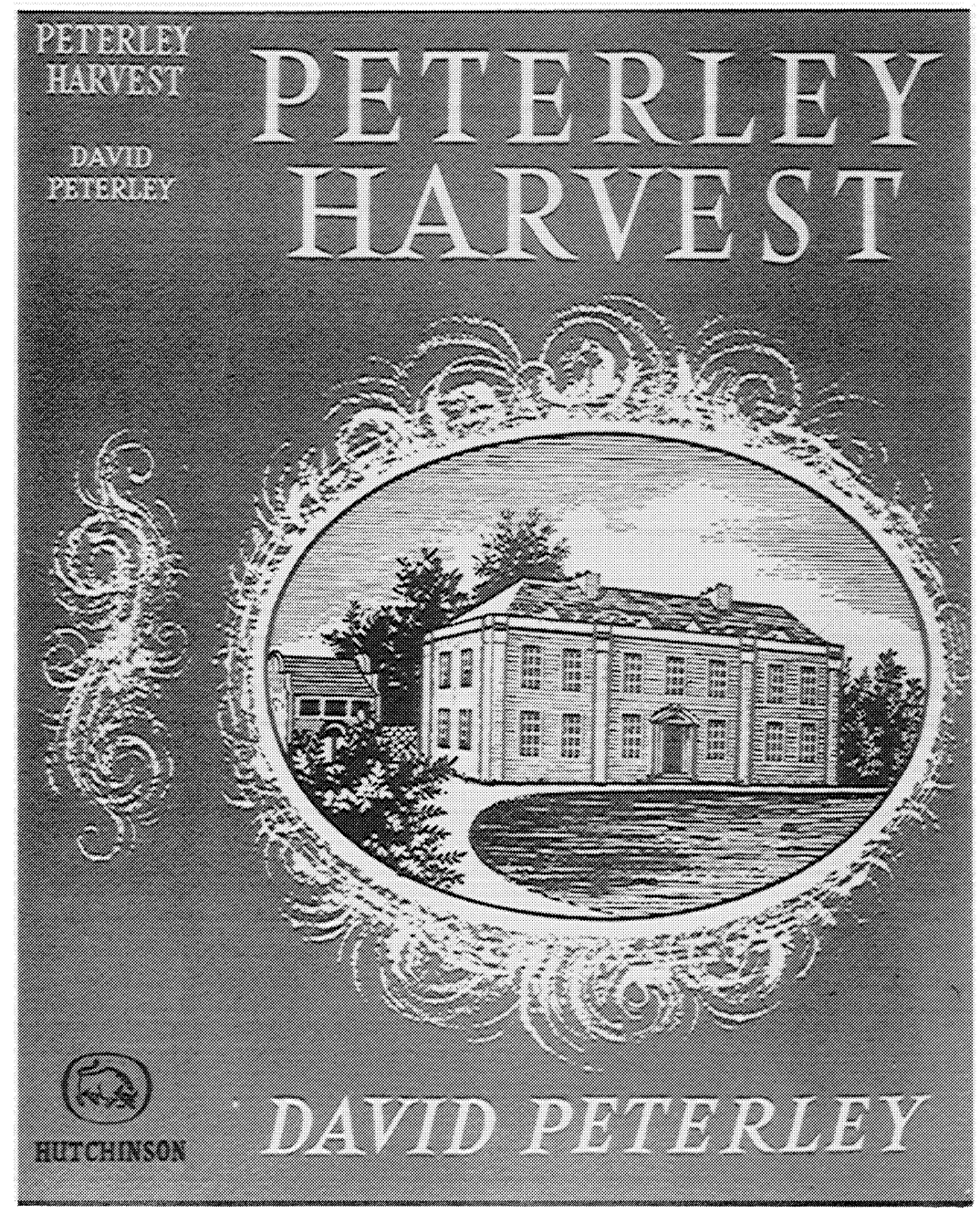

Wrapper designed by Patricia Davey for the first London edition, 1960, of Peterley Harvest.

An earlier version of the following paper was given at the $42 \mathrm{~d}$ Annual Meeting of the Bibliographical Society of Canada held at the University of British Columbia, Vancouver, British Columbia, on Io June 1987. 